University of Nebraska - Lincoln

DigitalCommons@University of Nebraska - Lincoln

U.S. Environmental Protection Agency Papers

U.S. Environmental Protection Agency

2008

Preservation and analytical procedures for the analysis of chloro-s-triazines and their chlorodegradate products in drinking waters using direct injection liquid chromatography tandem mass spectrometry

Glynda A. Smith

Shaw Environmental, Inc., 26 W. Martin Luther King Drive, Cincinnati, OH 45219, USA

Barry V. Pepich

Shaw Environmental, Inc., 26 W. Martin Luther King Drive, Cincinnati, OH 45219, USA

David J. Munch

US EPA Office of Groundwater and Drinking Water, 26 W. Martin Luther King Drive, Cincinnati, OH 45219, USA

Follow this and additional works at: https://digitalcommons.unl.edu/usepapapers

Part of the Civil and Environmental Engineering Commons

Smith, Glynda A.; Pepich, Barry V.; and Munch, David J., "Preservation and analytical procedures for the analysis of chloro-s-triazines and their chlorodegradate products in drinking waters using direct injection liquid chromatography tandem mass spectrometry" (2008). U.S. Environmental Protection Agency Papers. 13.

https://digitalcommons.unl.edu/usepapapers/13

This Article is brought to you for free and open access by the U.S. Environmental Protection Agency at DigitalCommons@University of Nebraska - Lincoln. It has been accepted for inclusion in U.S. Environmental Protection Agency Papers by an authorized administrator of DigitalCommons@University of Nebraska - Lincoln. 


\title{
Preservation and analytical procedures for the analysis of chloro-s-triazines and their chlorodegradate products in drinking waters using direct injection liquid chromatography tandem mass spectrometry
}

\author{
Glynda A. Smith ${ }^{\mathrm{a}, *}$, Barry V. Pepich ${ }^{\mathrm{a}}$, David J. Munch ${ }^{\mathrm{b}}$ \\ a Shaw Environmental, Inc., 26 W. Martin Luther King Drive, Cincinnati, OH 45219, USA \\ ${ }^{\mathrm{b}}$ US EPA Office of Groundwater and Drinking Water, 26 W. Martin Luther King Drive, Cincinnati, OH 45219, USA
}

\section{A R T I C L E I N F O}

\section{Article history:}

Received 10 April 2008

Received in revised form 12 June 2008

Accepted 26 June 2008

Available online 3 July 2008

\section{Keywords:}

Atrazine

Desethylatrazine

Desisopropylatrazine

Diaminochlorotriazine

Drinking water

Preservation

HPLC

MS/MS

\begin{abstract}
A B S T R A C T
A direct injection, liquid chromatography tandem mass spectrometry (LC-MS/MS) method has been developed for the analysis of the chloro-s-triazine herbicides and their degradates in finished drinking water. The target compounds in the method were selected based on their inclusion in a common mechanism group (CMG) because of their ability to induce a similar toxic effect through a common mechanism of toxicity. The target list includes the chloro-s-triazines (atrazine, simazine, cyanazine, and propazine) and their dealkylated degradates (desethylatrazine, desisopropylatrazine, and diaminochlorotriazine). Potential matrix effects are minimized by the use of individual isotopically enriched internal standards. Analyte stability in finished chlorinated drinking water samples is ensured through careful selection of proper dechlorinating and antimicrobial reagents and through buffering sample $\mathrm{pH}$. In the absence of proper dechlorination, the target analytes were found to degrade over a short period of time, even under refrigerated storage conditions. The final method has adequate sensitivity to accurately detect all target analytes at or below $0.1 \mu \mathrm{g} / \mathrm{L}$ and displays sufficient precision and robustness to warrant publication as EPA Method 536.

(ㄷ) 2008 Elsevier B.V. All rights reserved.
\end{abstract}

\section{Introduction}

The triazines are a class of pre- and post-emergent broadleaf herbicides that inhibit the growth of weeds by interfering with the normal function of photosynthesis [1]. Widespread agricultural application of these herbicides has resulted in an increased presence of these compounds, along with their degradation products, in both surface and ground waters [2-8]. Of the triazines, atrazine and simazine are currently regulated by the United States Environmental Protection Agency (EPA) in finished drinking water with maximum contaminant levels (MCLs) of 3.0 and $4.0 \mu \mathrm{g} / \mathrm{L}$, respectively [9]. For atrazine re-registration under the Federal Insecticide, Fungicide, and Rodenticide Act (FIFRA), EPA has set a performance standard level of concern based on atrazine and its chlorodegradates for drinking water monitoring [10].

In 2002, EPA published a report that evaluated a series of structurally similar triazine pesticides for inclusion in a common mechanism group (CMG) based on their ability to induce a similar toxic effect through a common mechanism of toxicity [11]. The

\footnotetext{
* Corresponding author. Tel.: +1 513569 7652; fax: +1 5135697837.

E-mail address: smith.glynda@epa.gov (G.A. Smith).
}

CMG included three of the 2-chloro-s-triazine parent compounds (atrazine, simazine, and propazine) and their chlorodegradation products [desethylatrazine (DEA), desisopropylatrazine (DIA), and diaminochlorotriazine (DACT)]. The compounds included in this group were determined to cause neuroendocrine-related developmental and reproductive effects, and to cause mammary tumors in rats. The pathway to tumor development, however, was not believed to be active in humans. The 2-hydroxy-s-triazine degradate was not included in the CMG because the neuoroendochrine studies were not conclusive, and because it was not found to cause mammary tumors in rats [11].

Since a number of triazines and their degradates have been found by EPA to have a common mechanism of toxicity, understanding the co-occurrence of these compounds in drinking water is important to determine whether regulating triazines as a group should be considered. In the future, if EPA were to consider taking regulatory action to address cumulative impacts of triazines, a robust analytical method would be a crucial component.

Triazines and their degradates have been studied in a number of Midwest occurrence surveys, which detected triazine pesticides and their degradation products in a significant percentage of the surface and groundwaters [2-8]. In a study of Iowa groundwaters, 
scientists at the USGS concluded that a majority of the measured concentration for the surveyed triazines (atrazine and cyanazine) was in the form of degradation products $[3,4]$.

Challenges associated with developing a single analytical method for the analysis of the CMG triazines and their degradates have been addressed by a number of researchers [12-17]. LC-MS [18] and, more recently, LC-MS/MS [19] methods have been published. The LC-MS researchers reported issues associated with matrix suppression and/or background interference, which led Huang et al. [19] to incorporate a 1:4 sample dilution prior to LC-MS/MS analysis of surface and groundwater samples. Generally, sample dilution can be used in instances in which the analyte concentrations are relatively high; however, at low levels such as those anticipated to be detected in finished drinking water samples, dilution of the samples to accommodate the higher concentration of interfering matrix components is undesirable. Huang et al. [19] concluded that isotope dilution with C-13 labeled triazine standards should also be evaluated for future applications.

This article describes work that was conducted to develop EPA Method 536, a direct injection, LC-MS/MS method for monitoring the chloro-s-triazines and their chlorodegradates in finished drinking water and the importance that proper preservation plays in maintaining sample integrity. Finished drinking waters give rise to the potential for degradation due to residual oxidants like free available chlorine, which are added to the waters prior to entry into the distribution systems to ensure water quality at the tap. Degradation can lead to analyte loss during sample storage and thus requires careful consideration in order to ensure that the measured analyte concentrations accurately reflect the field sample concentrations at the time and point of collection.

The method also includes cyanazine as a target analyte. While the production and application of cyanazine in the US was phased out between 1996 and 2002, it shares a common degradation pathway with the other CMG parent herbicides and its widespread use could result in its detection in groundwater for years.

\section{Materials and methods}

\subsection{Chemical and standard materials}

All target analytes were obtained as neat materials ( $\geq 95 \%$ ) from Riedel-de-Haan (Seelze, Germany). Second source target standards for DACT, DEA, DIA, simazine, and atrazine were obtained ( $\geq 96 \%)$ from ChemService (West Chester, PA); cyanazine and propazine were obtained ( $\geq 98 \%$ ) from Supelco (Bellefonte, PA). The following isotopically labelled internal standards were obtained from
Table 1

HPLC and electrospray MS conditions

\begin{tabular}{lll}
\hline HPLC gradient & & \\
\hline Time (min) & $5 \mathrm{mM} \mathrm{NH}_{4} \mathrm{OAC}$ (vol\%) & $\mathrm{MeOH}$ (vol\%) \\
\hline Initial & 90 & 10 \\
5.0 & 90 & 30 \\
25.0 & 70 & 40 \\
25.1 & 60 & 40 \\
35.0 & 60 & 50 \\
35.1 & 50 & 50 \\
45.0 & 50 & 10 \\
45.1 & 90 & 10 \\
65.0 & 90 & \\
& & \\
Electrospray MS conditions & & Positive ion mode \\
\hline Polarity & & $0.5 \mathrm{kV}$ \\
Capillary voltage & & $100^{\circ} \mathrm{C}$ \\
Source temperature & & $260^{\circ} \mathrm{C}$ \\
Desolvation temperature & & $600 \mathrm{~L} / \mathrm{h}$ \\
Desolvation gas flow & & $15 \mathrm{~L} / \mathrm{h}$ \\
Cone gas flow & $2.1 \mathrm{e}-3 \mathrm{mbar}$ \\
Collision cell pressure & Argon \\
Collision gas & \\
\hline
\end{tabular}

CDN Isotopes (Pointe Claire, Quebec, Canada): atrazine- $d_{5}$ (ethyl$d_{5}$; >99\% pure, 99.7 atom \%D), atrazine-desethyl- $d_{7}$ (> 98\%, 99.2 atom \%D), atrazine-desisopropyl- $d_{5}$ (ethyl- $d_{5} ; 98 \%, 99.7$ atom $\% \mathrm{D})$, cyanazine- $d_{5}$ ( $N$-ethyl- $d_{5} ;>99 \%, 99.7$ atom \%D), propazine$d_{14}$ (di-diisopropyl- $d_{14} ;>99 \%, 99.4$ atom \%D), and simazine- $d_{10}$ (diethyl- $d_{10} ;>99 \%, 99$ atom \%D). An isotopically labeled analogue was not commercially available for DACT. Atrazine-desethyldesisopropyl- ${ }^{13} \mathrm{C} 3$ was custom synthesized ( $\geq 98 \%$, 99 atom $\%{ }^{13} \mathrm{C} 3$ ) by Cambridge Isotope Laboratories (Andover, MA).

Standard stock solutions $(500 \mu \mathrm{g} / \mathrm{mL})$ were prepared in methanol $(\mathrm{MeOH})$. Due to limited solubility, DACT, DACT- ${ }^{13} \mathrm{C} 3$, simazine, and simazine- $d_{10}$ were prepared in methanol at $100 \mu \mathrm{g} / \mathrm{mL}$.

Methanol (HPLC Grade), ammonium acetate (98\%, HPLC Grade), and sodium hydroxide ( $50 \% \mathrm{w} / \mathrm{w}$, Certified) were obtained from Fisher Scientific (Lawn, NJ). Reagent water was obtained using a Millipore MilliQ Plus ${ }^{\mathrm{TM}}$ TOC System. Reagents used in dechlorination and preservation studies included sodium omadine ${ }^{\circledR}$ (sodium 2-pyridinethiol-1-oxide, $40 \mathrm{wt} . \%$ in water) obtained from Arch Chemicals (Norwalk, CT), sodium thiosulfate (>99\%) obtained from Fisher Scientific, and L-ascorbic acid (>99\%), sodium sulfite $(98 \%)$, citric acid (99\%), and diazolidinyl urea (DZU, 95\%) obtained from Sigma-Aldrich (St. Louis, MO).

$\mathrm{R}_{2} \mathrm{~A}$ agar growth media for heterotrophic plate studies was obtained from Difco Laboratories (Sparks, MD).

Table 2

Retention times, precursor and product ions, and collision energy used for each internal standard and target analyte

\begin{tabular}{|c|c|c|c|c|c|}
\hline Segment \# & Analyte & Retention time (min) & Precursor ion $(m / z)$ & Product ion $(m / z)$ & Collision Energy (eV) \\
\hline 1 & DACT-C ${ }^{13}$ (IS) & 3.78 & 149 & 105.5 & 22 \\
\hline 1 & DACT & 3.82 & 146 & 103.5 & 22 \\
\hline 2 & DIA- $d_{5}$ (IS) & 11.26 & 179 & 137 & 22 \\
\hline 2 & DIA & 11.57 & 174 & 132 & 22 \\
\hline 3 & DEA- $d_{7}$ (IS) & 18.66 & 195 & 147 & 22 \\
\hline 3 & DEA & 19.09 & 188 & 146 & 22 \\
\hline 4 & Simazine- $d_{10}$ (IS) & 30.48 & 212 & 137 & 20 \\
\hline 4 & Simazine & 30.96 & 202 & 132 & 20 \\
\hline 4 & Cyanazine- $d_{5}$ (IS) & 32.03 & 246 & 219 & 20 \\
\hline 4 & Cyanazine & 32.20 & 241 & 214 & 20 \\
\hline 5 & Atrazine- $d_{5}$ (IS) & 37.03 & 221 & 179 & 23 \\
\hline 5 & Atrazine & 37.37 & 216 & 174 & 23 \\
\hline 6 & Propazine- $d_{14}$ (IS) & 42.87 & 244 & 196 & 20 \\
\hline 6 & Propazine & 43.51 & 230 & 188 & 20 \\
\hline
\end{tabular}


Table 3

Detection limits and lowest concentration minimum reporting levels for the method analytes

\begin{tabular}{lll}
\hline Analyte & Calculated LCMRL $(\mu \mathrm{g} / \mathrm{L})$ & Calculated DL $(\mu \mathrm{g} / \mathrm{L})$ \\
\hline DACT & 0.14 & 0.028 \\
DIA & 0.11 & 0.043 \\
DEA & 0.026 & 0.017 \\
Simazine & 0.020 & 0.010 \\
Cyanazine & 0.027 & 0.010 \\
Atrazine & 0.037 & 0.010 \\
Propazine & 0.028 & 0.010 \\
\hline
\end{tabular}

\subsection{Instrumental conditions}

EPA Method 536 was developed using a Waters Alliance ${ }^{\mathrm{TM}} 2695$ high performance liquid chromatography (HPLC) system equipped with a Micromass Quattromicro ${ }^{\circledR}$ triple quadrupole mass spectrometer. A binary mobile phase consisting of $5 \mathrm{mM}$ ammonium acetate $\left(\mathrm{NH}_{4} \mathrm{OAc}\right)$ buffer ( $\left.\mathrm{pH} 6.5\right)$ and methanol at a constant flow rate of $0.25 \mathrm{~mL} / \mathrm{min}$ was used for the analysis. A $100-\mu \mathrm{L}$ aliquot of sample was injected and the analytes were separated with a Waters Xterra ${ }^{\circledR} \mathrm{RP} 18$ column $\left(2.1 \mathrm{~mm} \times 150 \mathrm{~mm}, 3.5 \mu \mathrm{m} d_{\mathrm{p}}\right)$. The analytes were quantitated using internal standard calibration and MS/MS detection with argon gas at a pressure of $1.9 \mathrm{e}-3 \mathrm{mbar}$ in the collision cell. Specific details regarding the LC gradient and MS/MS conditions are described in Tables 1 and 2.

\subsection{Assessment of triazine stability in chlorinated waters}

Triplicate samples of the target analytes $(2.0 \mu \mathrm{g} / \mathrm{L})$ were prepared in amber bottles containing reagent water (RW) (control), RW spiked with a commercial bleach solution $(3.4 \mathrm{mg} / \mathrm{L}$ free available chlorine, FAC), and finished chlorinated surface water $(0.84 \mathrm{mg} / \mathrm{L}$ FAC). All FAC concentrations were determined using a Hach DPD test kit. One set of samples was evaluated immediately (Day 0 ). The remaining samples were held for 2 days at $10^{\circ} \mathrm{C}$, then at $6^{\circ} \mathrm{C}$ as per current EPA Office of Groundwater and Drinking Water (OGWDW) requirements. A second set of samples was analyzed on Day 2 and the third set on Day 14.

\subsection{Sample preservation study conditions}

Preservation studies examined the effects of various antimicrobial agents and residual FAC on analyte recoveries by fortifying duplicate RW solutions containing $3 \mathrm{mg} / \mathrm{L}$ FAC with target analytes $(1-2 \mu \mathrm{g} / \mathrm{L})$ after the addition of the dechlorinating reagent and/or the buffer. Fortified samples containing the various test preservation reagents were prepared in amber bottles that were held at room temperature over at least a 7-day period to obtain data under accelerated stability study conditions. Ammonium chloride $(0.1 \mathrm{~g} / \mathrm{L})$, sodium thiosulfate $(0.08 \mathrm{~g} / \mathrm{L})$, sodium sulfite $(0.05 \mathrm{~g} / \mathrm{L})$, ascorbic acid $(0.1 \mathrm{~g} / \mathrm{L})$, and ammonium acetate $(1.5 \mathrm{~g} / \mathrm{L})$ were investigated as possible dechlorinating reagents. Two antimicrobial reagents were examined in RW without FAC: citric acid (potassium dihydrogen citrate, $9.3 \mathrm{~g} / \mathrm{L}, \mathrm{pH} 3.82$ ) and diazolidinyl urea (DZU, $1.0 \mathrm{~g} / \mathrm{L})$.

Another set of studies was conducted as above, but samples were fortified in triplicate with the target analytes at $5.0 \mu \mathrm{g} / \mathrm{L}$. Sodium omadine $(64 \mathrm{mg} / \mathrm{L})$ was evaluated for chemical compatibility as an antimicrobial, and the solutions were buffered and dechlorinated (when FAC was present) with $20 \mathrm{mM}$ ammonium acetate. FAC was added to a subset of the waters, as indicated in Table 5 , at $6 \mathrm{mg} / \mathrm{L}$.

\subsection{Storage stability study conditions}

Triplicate samples fortified with the target analytes at $5 \mu \mathrm{g} / \mathrm{L}$ were prepared in amber bottles containing fully preserved and nonpreserved finished chlorinated surface water in the presence and absence of a separate microbial spike. Samples were held for 2 days in a refrigerator maintained at $10^{\circ} \mathrm{C}$, then at $6^{\circ} \mathrm{C}$ for the remainder of the study. Samples were evaluated at 7-day increments over a 28-day period to assess analyte recovery as well as antimicrobial effectiveness through pour plate studies.

\subsection{Method performance study conditions}

Detection limits for Method 536 were determined in accordance with the procedure described by Glaser et al. [25] and lowest concentration minimum reporting levels (LCMRLs) were determined

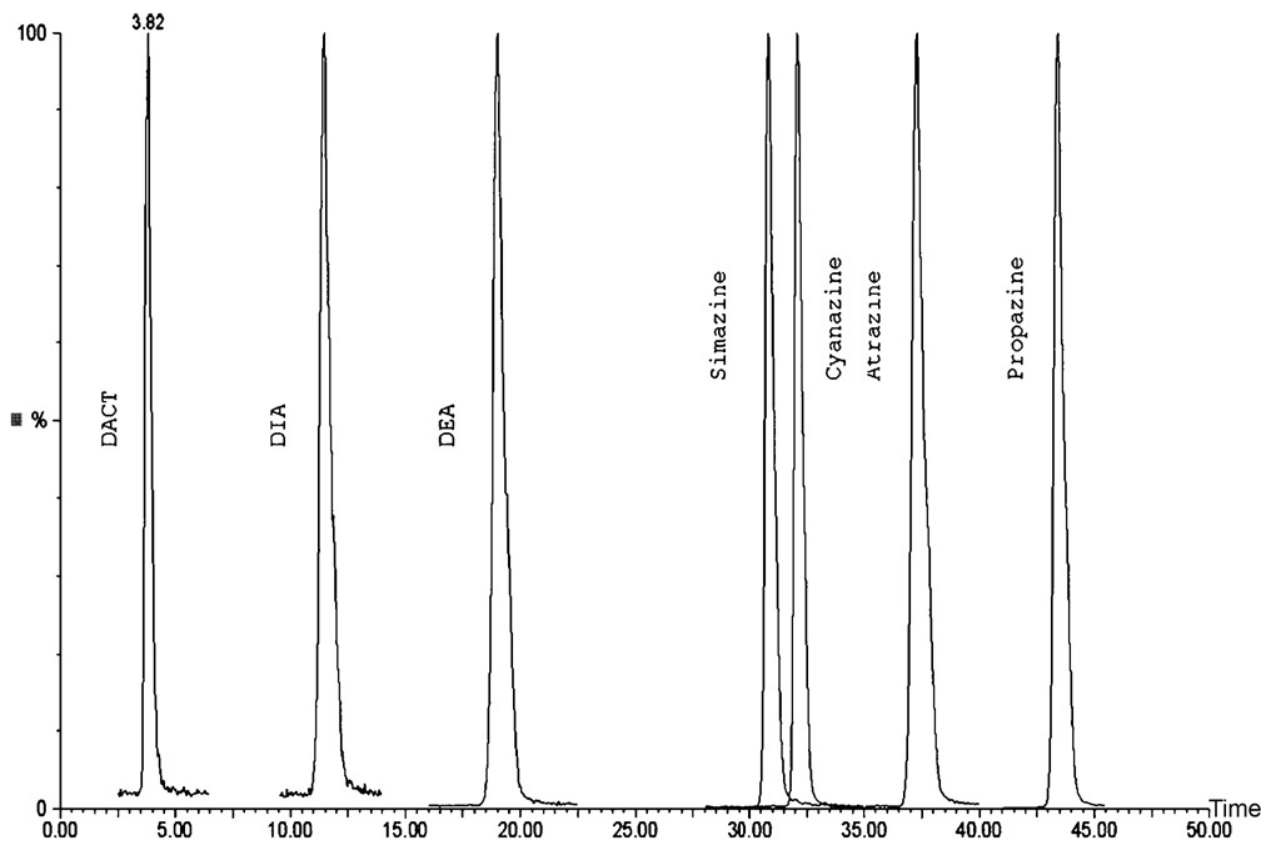

Fig. 1. Normalized, overlaid chromatograms of LC-MS/MS transitions for Method 536 analytes fortified at $0.5 \mu \mathrm{g} / \mathrm{L}$ in reagent water. 
Chlorinated Reagent Water

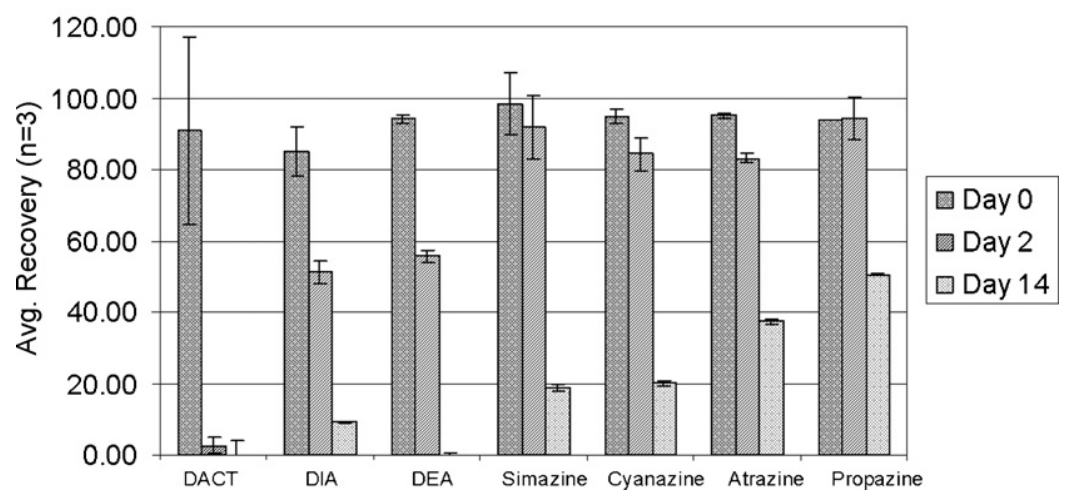

Fig. 2. Recovery data for target analytes fortified at $2 \mu \mathrm{g} / \mathrm{L}$ in chlorinated (FAC $=3.4 \mathrm{mg} / \mathrm{L}$ ) reagent water $(n=3)$.

according to the OGWDW procedure [26] and are tabulated in Table 3.

\section{Results and discussion}

\subsection{Method optimization}

The analytes were successfully resolved using a C18 column and a buffered binary gradient compatible with LC-MS. Fig. 1 shows the chromatogram for the product ion transitions for the Method 536 target compounds. Although MS/MS analysis is capable of distinguishing co-eluting compounds from one another, a good chromatographic separation minimizes the potential for suppression from co-eluting contaminants in the matrix.

One of the challenges associated with electrospray ionization (ESI) applications involves the performance of the ionization source in the presence of complex mixtures [20] and [21]. Matrix effects occur as a result of the co-elution of various organic and inorganic components in a sample along with the target analytes causing either an enhancement or suppression of target analyte signal response. Accuracy and precision are affected because the degree of enhancement or suppression can vary from one sample to another. Concentrated samples can be diluted in an effort to minimize the effect of matrix interferences on analyte signal responses. Such an approach, however, is undesirable for finished drinking water samples that contain the target analytes at low levels because dilution may result in false negative results for one or more of the analytes. An alternate solution is to use an appropriate internal standard which can balance the matrix effect on analyte signal with an equivalent effect on the internal standard. The ideal internal standards are the isotopically labeled target compounds that elute simultaneously or very near each analyte during chromatographic separation and are completely resolved by the mass spectrometer.

All of the chloro-s-triazines, and all but one degradate had deuterated analogues that were commercially available. $\mathrm{A}{ }^{13} \mathrm{C}$ enriched DACT standard was custom synthesized for these studies. During the interim while the DACT- ${ }^{13} \mathrm{C}$ was being prepared, DIA- $d_{5}$ was used as an internal standard for DACT. However, the application of this approach to a finished groundwater yielded enhanced DACT recoveries (>120\%). This problem was resolved after the DACT- ${ }^{13} \mathrm{C}$ internal standard was incorporated.

\subsection{Assessment of triazine stability in chlorinated drinking waters}

Although a number of investigators have developed methods employing various analytical techniques for the analysis of the triazines and their degradates [12-19], procedures to adequately protect the target compounds from microbiological or chemical degradation during storage have not been fully addressed. Huang et al. reported stability for atrazine, simazine and their dealkylated chlorotriazine metabolites if stored at refrigerated temperatures $\left(4^{\circ} \mathrm{C}\right)$ in the dark [19] and referenced an unpublished internal company document. Data presented in this paper, however, indicates that analyte degradation can be significant in chlorinated finished drinking water samples.

In 1997-1998, over 200 large public water systems collected disinfection residuals data as part of the Information Collection Rule (ICR) survey. FAC levels were found to be comparable for finished

Finished Chlorinated Surface Water Samples

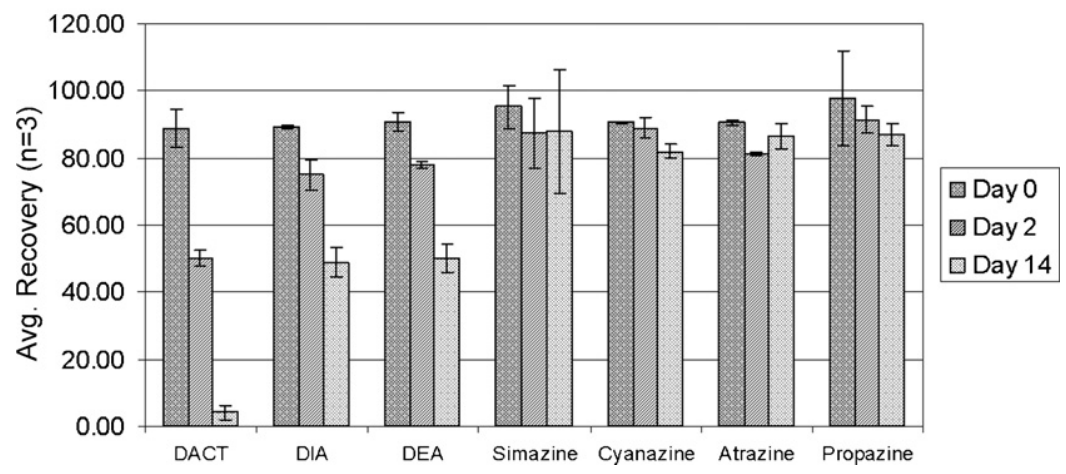

Fig. 3. Recovery data for target analytes fortified at $2 \mu \mathrm{g} / \mathrm{L}$ in finished chlorinated (FAC $=0.84 \mathrm{mg} / \mathrm{L})$ surface drinking water $(n=3)$. 
Table 4

Evaluation of target analyte recoveries for duplicate RW samples containing $3 \mathrm{mg} / \mathrm{L} \mathrm{FAC}$ preserved with different dechlorinating and antimicrobial reagents $(n=2)$.

\begin{tabular}{|c|c|c|c|c|c|c|c|c|}
\hline Analytes & Day & RW control & $\begin{array}{l}\text { Ammonium chloride } \\
(0.1 \mathrm{~g} / \mathrm{L})+3 \mathrm{mg} / \mathrm{L} \mathrm{Cl}_{2}\end{array}$ & $\begin{array}{l}\text { Sodium thiosulfate } \\
(0.08 \mathrm{~g} / \mathrm{L})+3 \mathrm{mg} / \mathrm{L} \\
\mathrm{Cl}_{2}\end{array}$ & $\begin{array}{l}\text { Sodium sulfite } \\
(0.05 \mathrm{~g} / \mathrm{L})+3 \mathrm{mg} / \mathrm{L} \\
\mathrm{Cl}_{2}\end{array}$ & $\begin{array}{l}\text { Citric acid } \\
(9.3 \mathrm{~g} / \mathrm{L})\end{array}$ & $\mathrm{DZU}(1.0 \mathrm{~g} / \mathrm{L})$ & $\begin{array}{l}\text { Ascorbic acid } \\
(0.1 \mathrm{~g} / \mathrm{L})+3 \mathrm{mg} / \mathrm{L} \\
\mathrm{Cl}_{2}\end{array}$ \\
\hline \multirow[t]{2}{*}{ DACT } & 0 & 89.4 & 94.1 & 78.0 & 76.4 & 23.6 & 89.5 & 108 \\
\hline & 8 & 92.2 & 89.7 & 77.6 & 85.8 & 0 & 67.5 & 69.0 \\
\hline \multirow[t]{2}{*}{ DIA } & 0 & 97.8 & 93.8 & 108 & 108 & 102 & 102 & 98.5 \\
\hline & 8 & 100 & 102 & 104 & 102 & 114 & 97.3 & 95.7 \\
\hline \multirow[t]{2}{*}{ DEA } & 0 & 95.3 & 94.7 & 104 & 104 & 101 & 100 & 99.1 \\
\hline & 8 & 101 & 102 & 104 & 104 & 99.2 & 99.1 & 99.8 \\
\hline \multirow[t]{2}{*}{ Cyanazine } & 0 & 97.3 & 97.8 & 101 & 103 & 96.6 & 102 & 103 \\
\hline & 8 & 102 & 97.1 & 101 & 101 & 109 & 97.3 & 99.9 \\
\hline \multirow[t]{2}{*}{ Simazine } & 0 & 99.0 & 104 & 120 & 119 & 94.0 & 104 & 106 \\
\hline & 8 & 107 & 103 & 113 & 110 & 113 & 107 & 99.8 \\
\hline \multirow[t]{2}{*}{ Atrazine } & 0 & 93.6 & 97.0 & 99.8 & 103 & 102 & 100 & 101 \\
\hline & 8 & 99.9 & 100 & 102 & 103 & 103 & 97.2 & 94.4 \\
\hline \multirow[t]{2}{*}{ Propazine } & 0 & 101 & 103 & 102 & 117 & 96.9 & 111 & 113 \\
\hline & 8 & 105 & 106 & 105 & 110 & 120 & 108 & 111 \\
\hline
\end{tabular}

water at both groundwater (median $\mathrm{FAC}=1.0 \mathrm{mg} / \mathrm{L}$ ) and surface water treatment plants (median $F A C=1.1 \mathrm{mg} / \mathrm{L}$ ) [22]. The maximum residual disinfectant level (MRDL) for FAC in finished drinking water is currently set at $4.0 \mathrm{mg} / \mathrm{L}$ under the Stage 2 Disinfection Byproducts Rule [23].

The effect of FAC on triazine stability during storage was assessed in RW containing FAC near the MRDL $(3.4 \mathrm{mg} / \mathrm{L})$ and in finished surface water with a FAC concentration $(0.84 \mathrm{mg} / \mathrm{L})$ near the reported ICR mean. Recovery results for triplicate samples are shown in Figs. 2-3. As the results indicate, residual FAC degrades analytes under storage conditions, and degradation increases with FAC concentration. For the RW fortified near the MRDL, substantial losses of the triazine degradates were noted by Day 2 and all recoveries were unacceptable by Day 14 . The RW control (included in Supplementary Data) performed acceptably. The results of this study emphasize the importance of proper dechlorination for all field samples, including those held even for short periods of time.

\subsection{Sample preservation studies}

Once residual FAC is removed from field samples, microbial regrowth during storage can also lead to analyte degradation. Therefore, an antimicrobial agent should be incorporated in field samples along with the dechlorinating reagent. A study was conducted to examine potential antimicrobial and dechlorinating reagents. Ammonium chloride, sodium thiosulfate, sodium sulfite, and ascorbic acid were investigated as potential dechlorinating reagents. Two antimicrobial reagents (citric acid and diazolidinyl urea, DZU) were also evaluated for their compatibility with the target analytes in the absence of FAC. LC-MS/MS analysis was performed on Day 0 to determine initial recoveries and again on Day 8. As the results in Table 4 indicate, citric acid rapidly degraded
DACT and DZU yielded borderline acceptable recoveries for DACT. The optimal dechlorinating reagent appeared to be ammonium chloride. Unlike the other dechlorinating reagents, which are all reducing agents, ammonium chloride sequesters FAC through successive equilibria to form less reactive chloramines.

The USDA Agricultural Research Service (ARS) Properties Database (http://www.ars.usda.gov) indicates that atrazine, simazine, cyanazine, and propazine may hydrolyze in acidic $(\mathrm{pH}<5.0)$ and basic $(\mathrm{pH}>9.0)$ environments. The database and other sources do not provide $\mathrm{pH}$ stability data for any of the degradates, however. Ammonium acetate $(5 \mathrm{mM})$ was chosen as the LC mobile phase for the method because it could maintain the mobile phase at near neutrality ( $\mathrm{pH} \sim 6.5$ ) while simultaneously removing FAC. A study to determine the buffer capacity of ammonium acetate in a high ionic strength finished groundwater concluded that samples should contain $20 \mathrm{mM}$ ammonium acetate as a buffer to prevent acid- or base-catalyzed hydrolysis. Conditions and results of the study are provided in Supplementary Data.

Another study was conducted to confirm the feasibility of using ammonium acetate as the dechlorinating reagent and to evaluate sodium omadine as an antimicrobial reagent. Previous work by Winslow et al. [24] described acceptable recoveries for cyanazine in field samples using sodium omadine $(64 \mathrm{mg} / \mathrm{L})$ to inhibit microbial activity. The dechlorination scheme was challenged with $6 \mathrm{mg} / \mathrm{L}$ of FAC, which is 50\% higher than the MRDL [22]. Triplicate RW samples were fortified with the target analytes at $5 \mu \mathrm{g} / \mathrm{L}$ and stored for 7 days at ambient temperature (Section 2.4). At the end of the 7-day holding period, samples were spiked with internal standards and analyzed. The recoveries for each analyte in the various combinations of sodium omadine, $20 \mathrm{mM}$ ammonium acetate, and added FAC are summarized in Table 5.

Table 5

Day 7 analyte recoveries for second antimicrobial/dechlorination study $(n=3)$

\begin{tabular}{|c|c|c|c|c|c|c|}
\hline Analytes & RW Control & $20 \mathrm{mM} \mathrm{NH}_{4} \mathrm{OAc}$ & $\begin{array}{l}20 \mathrm{mM} \\
\mathrm{NH}_{4} \mathrm{OAc}+6 \mathrm{mg} / \mathrm{L} \mathrm{Cl}_{2}\end{array}$ & $\begin{array}{l}\text { Sodium omadine } \\
\text { at } 64 \mathrm{mg} / \mathrm{L} \text { level }\end{array}$ & $\begin{array}{l}\text { Omadine + } 20 \mathrm{mM} \\
\mathrm{NH}_{4} \mathrm{OAc}\end{array}$ & $\begin{array}{l}\text { Omadine }+20 \mathrm{mM} \\
\mathrm{NH}_{4} \mathrm{OAc}+6 \mathrm{mg} / \mathrm{L} \mathrm{Cl}_{2}\end{array}$ \\
\hline DACT & 108 & 113 & 91.2 & 107 & 98.3 & 100 \\
\hline DIA & 100 & 100 & 88.4 & 102 & 95.4 & 97.5 \\
\hline DEA & 95.2 & 97.3 & 91.2 & 92.8 & 91.9 & 94.4 \\
\hline Simazine & 99.0 & 100 & 89.4 & 91.3 & 85.7 & 88.3 \\
\hline Cyanazine & 95.0 & 96.0 & 92.5 & 87.7 & 80.0 & 88.6 \\
\hline Atrazine & 94.1 & 94.4 & 94.4 & 92.9 & 91.2 & 92.7 \\
\hline Propazine & 95.7 & 96.8 & 89.5 & 91.0 & 90.0 & 92.7 \\
\hline
\end{tabular}




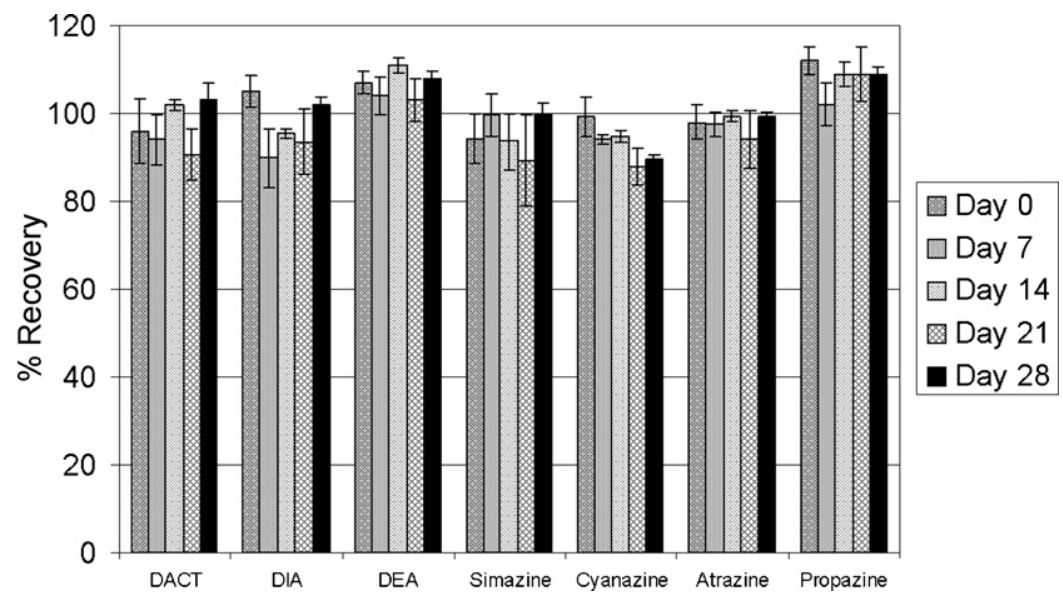

Fig. 4. Sample holding time recovery data for target analytes fortified at $5 \mu \mathrm{g} / \mathrm{L}$ in fully preserved finished chlorinated surface drinking water $(n=3)$.

As the results indicate, DACT was recovered at $>90 \%$ when $20 \mathrm{mM}$ ammonium acetate was used in the presence of $6 \mathrm{mg} / \mathrm{L}$ FAC. These data also indicate that the target analytes were stable in the presence of the relatively high levels of chloramines that were formed during sequestration. Chloramines are often used as an alternate disinfectant for source waters that contain high levels of total organic carbon to mitigate the formation of halogenated disinfection byproducts. As opposed to citric acid and DZU, sodium omadine at a level of $64 \mathrm{mg} / \mathrm{L}$ did not result in loss of recovery for any of the target analytes.

\subsection{Additional method considerations}

In addition to incorporation of isotopically enriched internal standards and selection of appropriate dechlorinating and antimicrobial reagents, other factors were identified during method development. For example, a positive bias was observed when preserved samples were evaluated using calibration standards prepared in only RW. The use of procedural calibration standards that incorporated $20 \mathrm{mM}$ ammonium acetate and $64 \mathrm{mg} / \mathrm{L}$ sodium omadine eliminated this bias.

An attempt was also made to shorten the analysis time by installing a $2.1 \mathrm{~mm} \times 100 \mathrm{~mm}$ analytical column packed with larger diameter particles $(5 \mu \mathrm{m})$. This worked well in reagent water samples; however, in both finished ground water and surface water samples, the responses for DACT and DACT ${ }^{13} \mathrm{C}$ were almost completely suppressed. The source of the signal suppression could not be determined; however, it is likely some low-level, co-eluting contaminant was responsible. The $2.1 \mathrm{~mm} \times 150 \mathrm{~mm}$ analytical column with smaller diameter particles $(3.5 \mu \mathrm{m})$ was re-installed, and the analyte responses recovered in all the drinking water matrices. EPA Method 536 permits flexibility with regard to the use of alternate columns, mobile phase compositions and instrumental conditions. However, it is important to maintain chromatographic resolution

Table 6

Method 536 precision and accuracy in RW, surface water and groundwater

\begin{tabular}{|c|c|c|c|c|}
\hline \multirow[t]{2}{*}{ Analyte } & \multicolumn{2}{|c|}{ Fort. conc. $=0.5 \mu \mathrm{g} / \mathrm{L}(n=7)$} & \multicolumn{2}{|c|}{ Fort. conc. $=5.0 \mu \mathrm{g} / \mathrm{L}(n=7)$} \\
\hline & $\% \operatorname{Rec}$ & \%RSD & $\% \operatorname{Rec}$ & $\%$ RSD \\
\hline \multicolumn{5}{|c|}{ Precision and accuracy in reagent water } \\
\hline DACT & 98.9 & 4.9 & 89.4 & 4.2 \\
\hline DIA & 100 & 3.4 & 96.1 & 3.7 \\
\hline DEA & 99.4 & 2.7 & 97.6 & 1.3 \\
\hline Simazine & 101 & 3.0 & 101 & 1.9 \\
\hline Cyanazine & 97.7 & 1.3 & 99.3 & 1.4 \\
\hline Atrazine & 99.4 & 2.5 & 99.7 & 1.6 \\
\hline Propazine & 103 & 2.9 & 99.0 & 2.0 \\
\hline \multicolumn{5}{|c|}{ Precision and accuracy in surface water ${ }^{\mathrm{a}}$} \\
\hline DACT & 102 & 8.4 & 103 & 2.7 \\
\hline DIA & 100 & 6.6 & 101 & 3.7 \\
\hline DEA & 95.5 & 1.5 & 97.9 & 0.9 \\
\hline Simazine & 94.5 & 3.7 & 99.4 & 1.7 \\
\hline Cyanazine & 95.3 & 4.2 & 99.4 & 1.7 \\
\hline Atrazine & 97.4 & 6.1 & 101 & 0.9 \\
\hline Propazine & 94.9 & 6.0 & 105 & 1.5 \\
\hline \multicolumn{5}{|c|}{ Precision and accuracy in groundwater ${ }^{\mathrm{b}}$} \\
\hline DACT & 106 & 3.5 & 95.7 & 2.5 \\
\hline DIA & 99.6 & 5.2 & 103 & 3.0 \\
\hline DEA & 95.7 & 1.7 & 98.6 & 1.5 \\
\hline Simazine & 94.6 & 3.1 & 98.0 & 1.5 \\
\hline Cyanazine & 93.5 & 1.8 & 101 & 1.3 \\
\hline Atrazine & 96.7 & 0.9 & 100 & 1.5 \\
\hline Propazine & 91.7 & 3.7 & 99.7 & 1.4 \\
\hline
\end{tabular}

a Surface water physical parameters: pH 7.1; hardness, $154 \mathrm{mg} / \mathrm{L}$; free chlorine, $1.5 \mathrm{mg} / \mathrm{L}$ (Hach).

b Ground water physical parameters: $\mathrm{pH} 7.5$; hardness, $360 \mathrm{mg} / \mathrm{L}$; free chlorine, $0.49 \mathrm{mg} / \mathrm{L}$. 
of the target analytes rather than shortening analysis time by relying too heavily on LC-MS/MS specificity since matrix effects are not eliminated when MS/MS is employed for detection.

\subsection{Storage stability studies}

Studies were conducted to verify the analyte storage stability in the presence of the method preservatives and to confirm the effectiveness of the antimicrobial reagents. Fortified finished chlorinated surface water samples were prepared, stored according to the conditions (described above), and evaluated at 7-day increments over a 28-day period. Target compound recovery data are presented in Fig. 4 for finished chlorinated surface water. As the data indicate, all of the analytes exhibited acceptable storage stability over this period.

Pour plate studies confirmed the effectiveness of sodium omadine as an antimicrobial. Although the positive control pour plates indicated a vigorous microbial population (average $\mathrm{CFU} / \mathrm{mL}$ per sample $=663$ ), all other samples had virtually no growth because the ammonium acetate buffer yielded a residual chloramine that was persistent throughout the storage period (total chlorine $0.8 \mathrm{mg} / \mathrm{L}$ ). The US water systems that do not rely on chlorination for disinfection would not be afforded the secondary protection of chloramines; however, the original work done by Winslow et al. confirmed the antimicrobial effectiveness of sodium omadine in pour plate studies using ascorbic acid as the dechlorinating reagent [24].

\subsection{Method performance}

The Method 536 detection limits (DLs) were determined in accordance with the procedure described by Glaser et al. [25] and ranged from 0.010 to $0.043 \mu \mathrm{g} / \mathrm{L}$ for the method analytes. The lowest concentration minimum reporting levels (LCMRLs) were determined in accordance with the EPA OGWDW procedure [26] and ranged from 0.020 to $0.14 \mu \mathrm{g} / \mathrm{L}$. DL and LCMRL results are shown in Table 3. Recovery data for low-level fortified and preserved reagent water samples $(n=7)$ are as follows: diaminochlorotriazine recovery of $108 \pm 8.1 \%$ at $0.10 \mu \mathrm{g} / \mathrm{L}$; desisopropylatrazine recovery of $105 \pm 12.6 \%$ at $0.10 \mu \mathrm{g} / \mathrm{L}$; desethylatrazine recovery of $102 \pm 7.1 \%$ at $0.05 \mu \mathrm{g} / \mathrm{L}$; simazine recovery of $104 \pm 5.6 \%$ at $0.05 \mu \mathrm{g} / \mathrm{L}$; cyanazine recovery of $92.6 \pm 5.8 \%$ at $0.05 \mu \mathrm{g} / \mathrm{L}$; atrazine recovery of $108 \pm 3.8 \%$ at $0.05 \mu \mathrm{g} / \mathrm{L}$; and propazine recovery of $104 \pm 4.7 \%$ at $0.05 \mu \mathrm{g} / \mathrm{L}$.

Precision and accuracy were determined for the method analytes in three different finished drinking water matrices, preserved and fortified at two levels. The matrices examined included reagent water, finished chlorinated surface water that contains moderate levels of total organic carbon (TOC), and finished chlorinated ground water with hardness greater than $300 \mathrm{mg} / \mathrm{L}$. The average recoveries and percent relative standard deviations for seven replicate samples are summarized in Table 6. Method performance was determined to be comparable in a second, independent laboratory.

\section{Conclusions}

Data presented herein demonstrate the importance of proper preservation techniques, and in particular dechlorination. Without proper removal of FAC, chlorinated waters, which are common in the US, have the potential to yield results that significantly underestimate the total triazine concentrations even when stored for short periods of time. This effect is of greatest concern for the degradates and is most pronounced for DACT. Previous and/or future survey work conducted on chlorinated groundwaters could be most impacted by this finding, since triazine degradates have already been determined to comprise a majority of the triazine constituents in this matrix.

\section{Acknowledgments}

All work was supported on-site at the EPA's Drinking Water Laboratory located in Cincinnati, Ohio. This work has been funded wholly or in part by the United States Environmental Protection Agency under an on-site contract (Contract EP-C-06-031) to Shaw Environmental \& Infrastructure. It has been subject to the Agency's review, and it has been approved for publication as an EPA document. Mention of trade names or commercial products does not constitute endorsement or recommendation for use.

\section{Appendix A. Supplementary data}

Supplementary data associated with this article can be found, in the online version, at doi:10.1016/j.chroma.2008.06.033.

\section{References}

[1] M. Graymore, F. Stagnitti, G. Allinson, Environ. Int. 26 (2001) 483.

[2] R.A. Boyd, Sci. Total Environ. 248 (2000) 241.

[3] D.W. Kolpin, E.M. Thurman, S.M. Linhart, Environ. Sci. Technol. 35 (2001) 1217

[4] D.W. Kolpin, E.M. Thurman, S.M. Linhart, Sci. Total Environ. 248 (2000) 115.

[5] D.W. Kolpin, E.M. Thurman, S.M. Linhart, Environ. Contam. Toxicol. 35 (1998) 385.

[6] D.W. Kolpin, E.M. Thurman, D.A. Goolsby, Environ. Sci. Technol. 30 (1996) 335.

[7] E.M. Thurman, M.T. Meyer, M.S. Mills, L.R. Zimmerman, C.A. Perry, Environ. Sci. Technol. 28 (1994) 2267.

[8] E.M. Thurman, D.A. Goolsby, M.T. Meyer, M.S. Mills, M.L. Pomes, D.W. Kolpin, Environ. Sci. Technol. 26 (1992) 2440.

[9] U.S. EPA, National Primary Drinking Water Regulations, 40 CFR 141, subpart 141.50, 1992, p. 424

[10] U.S. EPA, Pesticides Reregistration, Atrazine Reregistration Updates, http:// www.epa.gov/oppsrrd1/reregistration/atrazine/atrazine_update.htm.

[11] U.S. EPA, Office of Pesticides Programs, Health Effects Division, Document \#EPAHQ-OPP-2005-0481-0011, March 2002.

[12] S.Y. Panshin, D.S. Carter, E.R. Bayless, Environ. Sci. Technol. 34 (2000) 2131

[13] I. Tolosa, B. Douy, F.P. Carvalho, J. Chromatogr. A 864 (1999) 121.

[14] Z. Cai, M.L. Gross, R.F. Spalding, Anal. Chem. Acta 304 (1995) 67.

[15] S. Huang, J.S. Stanton, Y. Lin, R.A. Yokley, J. Agric. Food Chem. 51 (2003) 7252.

[16] H. Jiang, C.D. Adams, W. Koffskey, J. Chromatogr. A 1064 (2005) 219.

[17] R. Carabias-Martinez, E. Rodriguez-Gonzalo, E. Herrero-Hernandez, F.J.S. Roman, M.G.P. Flores, J. Chromatogr. A 950 (2002) 157.

[18] A. Di Corcia, C. Crescenzi, E. Guerriero, R. Samperi, Environ. Sci. Technol. 31 (1997) 1658.

[19] S. Huang, T.J. Mayer, R.A. Yokley, R. Perez, J. Agric. Food Chem. 54 (2006) 713.

[20] B.K. Choi, D.M. Hercules, A.I. Gusev, J. Chromatogr. A 907 (2001) 337.

[21] A.P. Bruins, J. Chromatogr. A 794 (1998) 345.

[22] U.S. EPA, Office of Water, EPA Document \#815-R-05-011, December 2005.

[23] U.S. EPA, National Primary Drinking Water Regulations: Stage 2 Disinfectants and Disinfection Byproducts Rule; Final Rule. Fed. Regist., 71(2), January 2006, p. 388 .

[24] S.D. Winslow, B.V. Pepich, M.V. Bassett, S.C. Wendelken, Environ. Sci. Technol. 35 (2001) 4103.

[25] J.A. Glaser, D.L. Forest, G.D. McKee, S.A. Quave, W.L. Budde, Environ. Sci. Technol. 15 (1981) 1426.

[26] U.S. EPA, Office of Ground Water and Drinking Water, EPA Document \#815-R05-006, November 2004. 